\title{
PENERAPAN CASE BASED REASONING UNTUK SISTEM DIAGNOSIS PENYAKIT HEPATITIS
}

\author{
Miswar Papuangan ${ }^{l}$ \\ Program Studi Teknik Informatika, Fakultas Teknik, Universitas Pasifik Morotai \\ Jl. Siswa Darame Kec. Morotai Selatan Kab. Pulau Morotai \\ E-mail : ${ }^{1}$ miswarpapuangan@gmail.com
}

Abstract -- Hepatitis is a liver disorder such as inflammation in the cells or liver tissue were classified as infectious diseases. Inflammation is characterized by elevated levels of liver enzymes. This increase is due to an interference or damage to liver membranes. Popularly also known as liver disease, liver sick or jaundice. Hepatitis can be caused by various causes such as viruses, bacteria, parasites, fungi, drugs, chemicals, alcohol, worms, malnutrition, and even autoimmune. Hepatitis disease can affect anyone regardless of age. This study implements the CBR to assist in the diagnosis of hepatitis disease. The process of diagnosis is done by inserting a new problem containing the symptoms and risk factors that will be diagnosed in the system, then the process of calculating the value of the similarity between the new problems with the cases that are stored in the case base using the nearest neighbor method normalized with a confidence level of experts. Testing was conducted using 117 cases data with 82 cases stored in the case base and the data 35 cases who made as a new case. Results of testing the system using data from medical records of patients with a diagnosis of validated experts indicate that the system is able to identify three types of hepatitis disease with accuracy rate of $94.29 \%$.

Keywords : Case-Based Reasoning, Nearest Neighbor, Hepatitis

Abstrak - Hepatitis merupakan kelainan hati berupa peradangan pada sel-sel atau jaringan hati yang tergolong penyakit menular. Peradangan ditandai dengan peningkatan kadar enzim hati. Peningkatan ini disebabkan adanya gangguan atau kerusakan membran hati. Secara popular dikenal juga dengan istilah penyakit hati, sakit liver atau sakit kuning. Hepatitis dapat disebabkan oleh berbagai macam penyebab seperti virus, bakteri, parasit, jamur, obat-obatan, bahan kimia, alkohol, cacing, gizi buruk, dan bahkan autoimun. Penyakit hepatitis dapat menyerang siapa saja tidak pandang usia. Penelitian ini mengimplementasikan CBR untuk membantu melakukan diagnosis penyakit hepatitis. Proses diagnosis dilakukan dengan cara memasukkan permasalahan baru yang berisi gejala-gejala dan faktor resiko yang akan di diagnosis ke dalam sistem, kemudian melakukan proses perhitungan nilai similaritas antara permasalahan baru dengan kasus-kasus yang tersimpan di basis kasus menggunakan metode nearest neighbor yang dinormalisasikan dengan tingkat keyakinan pakar. Pengujian dilakukan dengan menggunakan 117 kasus dengan 82 kasus yang disimpan di basis kasus dan 35 data kasus yang dijadikan sebagai kasus baru. Hasil pengujian sistem dengan menggunakan data rekam medik pasien dengan diagnosis yang tervalidasi pakar menunjukkan bahwa sistem mampu mengenali tiga jenis penyakit hepatitis dengan tingkat akurasi sebesar $94,29 \%$.

Kata Kunci : Penalaran Berbasis Kasus, Nearest Neighbor, Hepatitis

\section{PENDAHULUAN}

Hepatitis merupakan suatu proses peradangan pada jaringan hati yang tergolong penyakit menular. Secara popular dikenal juga dengan istilah penyakit hati, sakit liver atau sakit kuning Hepatitis dapat disebabkan oleh berbagai macam penyebab seperti virus, bakteri, parasit, jamur, obat-obatan, bahan kimia, alkohol, cacing, gizi buruk, dan bahkan autoimun. Penyakit hepatitis terbanyak disebabkan oleh virus. Penyakit hepatitis yang disebabkan oleh infeksi virus hepatitis masih merupakan penyakit endemis di Indonesia. Sebagian besar viral hepatitis disebabkan oleh infeksi virus hepatitis A, B, C, D, E (Dienstag dan Isselbacher, 2001).

Untuk mendiagnosis pasien yang menderita penyakit hepatitis dapat diketahui gejala-gejala yang muncul atau dialami oleh pasien dan faktor resiko yang dirasakan pasien. Penanganan pada pasien penyakit hepatitis dilakukan oleh dokter spesialis penyakit hepatitis, namun karena keterbatasan ketersediaan dokter spesialis penyakit hepatitis mengakibatkan lambatnya diagnosis pasien, maka dibutuhkan suatu alat yang dapat membantu untuk diagnosis pasien penderita penyakit hepatitis. 
Alat bantu bisa berupa sistem pakar berbasis pengetahuan untuk diagnosis suatu penyakit. Terdapat banyak metode yang dapat digunakan dalam pengembangan sebuah sistem pakar, khususnya pengembangan sistem pakar dalam dunia medis, salah satunya dengan menggunakan penalaran berbasis kasus (CBR). CBR merupakan metode yang popular digunakan dalam pembuatan sebuah sistem cerdas. Untuk sistem pernalaran berbasis kasus, kelebihan yang ditawarkan dengan menggunakan metode ini adalah akuisisi dan manajemen pengetahuan yang mudah dilakukan, dapat melakukan incremental learning, bersifat fleksibel dan adaptif.

\section{METODE PENELITIAN}

\section{Case Based Reasoning}

Case-Based Reasoning sudah banyak dimanfaatkan banyak pengguna, ada tiga fungsi yang berbeda dari CBR berdasarkan tingkat keterlibatan pengguna yang semakin meningkat yaitu sebagai Diagnosis, Pendukung Keputusan, dan Manajemen Pengetahuan (Althoff, 2001).

Case based reasoning (CBR) telah diaplikasikan dalam banyak bidang yang berbeda dan telah teruji. Diantaranya : hukum, kedokteran, rekayasa, komputasi, jaringan komunikasi, desain pabrik, keuangan, penjadwalan, bahasa, sejarah, makanan/nutrisi, penemuan rute dan lingkungan (Mulyana dan Hartati, 2009). Inti dari CBR adalah menggunakan pengetahuan lama untuk memecahkan permasalahan baru. Penyajian pengetahuan (knowledge representation) dibuat dalam bentuk kasus-kasus (cases). Setiap kasus berisi masalah (problem) dan solusi (solution) (Tempola, dkk. 2017).

Cara kerja CBR dengan membandingkan kasus baru dengan kasus lama. Jika kasus baru tersebut mempunyai kemiripan dengan kasus lama maka CBR akan memberikan jawaban kasus lama untuk kasus baru tersebut. Jika tidak ada yang cocok maka CBR akan melakukan adaptasi dengan memasukkan kasus baru tersebut ke dalam basis data penyimpanan kasus (case base), sehingga secara tidak langsung pengetahuan CBR akan bertambah (Rismawan dan Hartati, 2012).

\section{Pengukuran Similaritas}

Ketika ada permasalahan baru yang muncul maka langkah pertama adalah mengambil kasus-kasus yang disimpan di dalam basis kasus dengan cara melakukan pengukuran similaritas. Pengukuran similaritas akan menghasilkan nilai yang menentukan tentang ada atau tidak kemiripan antara kasus yang baru dengan kasus-kasus yang ada dalam basis kasus dengan membandingkan fitur yang ada pada kasus baru dengan sejenis yang ada pada basis kasus. Suatu kasus disebut indentik dengan kasus lain apabila nilai similaritasnya sama dengan 1, dan jika dikatakan mirip jika nilainya dibawah 1. Pengukuran similaritas yang digunakan dalam penelitian ini mencakup :

\section{a. Similaritas Lokal}

Similaritas lokal menunjukan kesamaan antara atribut permasalahan baru terhadap atribut yang tersimpan dalam basis kasus. Persamaan (1) untuk menghitung similaritas lokal untuk tipe data numerik (Jha dkk. 2013).

$$
f(s, t)=1-\frac{|s-t|}{R}
$$

Dimana, $s, \quad t$ adalah nilai fitur yang ingin dibandingkan dan $R$ adalah range nilai untuk fitur tersebut.

Untuk tipe data Boolean, berlaku fungsi similaritas lokal (Nurdiansyah dan Hartati, 2014). Menggunakan persamaan (2).

$$
f(s, t)=\left\{\begin{array}{l}
1 \text { jika } s=t \\
0 \text { jika } s \neq t
\end{array}\right.
$$

\section{b. Pengkuran Tingkat Keyakinan}

Tingkat keyakinan suatu permasalahan baru pada CBR adalah indentik dengan suatu kasus yang telah ada dihitung berdasarkan kesamaan atribut yang ada pada keduanya. Untuk menghitung tingkat keyakinan bahwa suatu permasalahan baru $(T)$ merupakan bagian dari sebuah kelas dalam basis kasus $(S)$ menggunakan persamaan 3 (Pal dan Shiu, 2004).

$$
\mu(S, T)=\frac{J\left(s_{i, T_{i}}\right)}{J\left(T_{i}\right)}
$$

Keterangan :

$\mu(S, T)$ : Tingkat keyakinan kasus $T$ identik dengan kasus $S$

$J\left(S_{i}, T_{i}\right)$ : Banyaknya atribut kasus $T$ yang sama dengan kasus $S$

$J\left(T_{i}\right)$ : Banyaknya atribut yang muncul pada target case

\section{c. Similaritas Global}

Digunakan untuk menghitung kemiripan antara kasus baru dengan kasus yang tersimpan dalam basis kasus. Salah satu metode pengukuran similaritas global yang sering digunkan yaitu nearest neighbor (Ong dkk. 1997). Dengan pembobotan menggunakan persamaan (4).

$$
\operatorname{SimNN}(S, T)=\frac{\sum_{i=1}^{n} f\left(S_{i, T_{i}}\right) *\left(W_{i}\right)}{\sum_{i=1}^{n} W_{i}}
$$

Keterangan : 
$\operatorname{SimNN}(S, T)$ : Similaritas global antara source case $(S)$ dan target case $(T)$

$T \quad$ : Kasus baru

$S \quad$ : Kasus yang ada dalam basis kasus

$n \quad$ : Banyaknya atribut dalam tiap kasus

$i \quad$ : Atribut individu antara 1 sampai dengan $n$

$f\left(S_{i}, T_{i}\right) \quad$ : Fungsi similaritas lokal atribut ke- $i$ antara kasus $S$ dan kasus $T$ atribut ke- $i$

$W_{i} \quad$ : Nilai bobot yang diberikan pada

Persamaan dimodifikasi dengan menambah faktor tingkat keyakinan sebagaimana ditunjukan oleh persamaan (5)

$$
\operatorname{SimNN}(S, T)=\frac{\sum_{i=1}^{n} f\left(S_{i,} T_{i}\right) *\left(W_{i}\right)}{\sum_{i=1}^{n} W_{i}} * P(S) * \frac{J\left(S_{i}, T_{i}\right)}{J\left(T_{i}\right)}
$$

Keterangan :

$\operatorname{Sim} N N(S, T)$ : Similaritas global antara kasus $S$ dan kasus $T$

$f\left(S_{i}, T_{i}\right) \quad$ : Similaritas lokal atribut ke- $i$ antara kasus $S$ dan kasus $T$

$n \quad$ : Banyaknya atribut dalam tiap kasus

$S_{i} \quad$ : Atribut ke- $i$ dari source case

$T_{i} \quad:$ Atribut ke- $i$ dari target case

$W_{i} \quad$ : Nilai bobot atribut ke- $i$ pada penyakit dari source case

$P(S) \quad$ : Persentase tingkat keyakinan pakar terhadap source case

$J\left(S_{i}, T_{i}\right)$ : Banyaknya atribut dalam kasus $T$ identik dengan kasus $S$

$J\left(T_{i}\right) \quad$ : Banyaknya atribut yang muncul pada target case

\section{Pengujian Sistem}

Akurasi yaitu tingkat kedekatan pengukuran kuantitas terhadap nilai yang sebenarnya. Pengukuran akurasi dilakukan dengan membandingkan jumlah diagnosis benar oleh sistem dengan jumlah data uji. Perbandingan dapat dituliskan dalam bentuk persamaan (6) (Witten dan Frank, 2005).

$$
\text { Akurasi }=\frac{\sum \text { diagnosa benar }}{\sum \text { data } u j i} \times 100 \%
$$

\section{Diagram Konteks}

Diagram konteks merupakan diagram yang terdiri dari suatu proses dan menggambarkan ruang lingkup suatu sistem. Diagram konteks merupakan level tertinggi dari DFD yang menggambarkan suatu sistem terkait dengan dokumen keluaran dan masukkan serta entitas yang berhubungan dengan sistem. Sistem CBR diagnosis penyakit hepatitis ini berhubungan dengan tiga entitas pengguna, yaitu pakar, paramedis, dan admin.. Diagram konteks pada sistem CBR diagnosis penyakit hepatitis seperti ditunjukan pada Gambar 1.

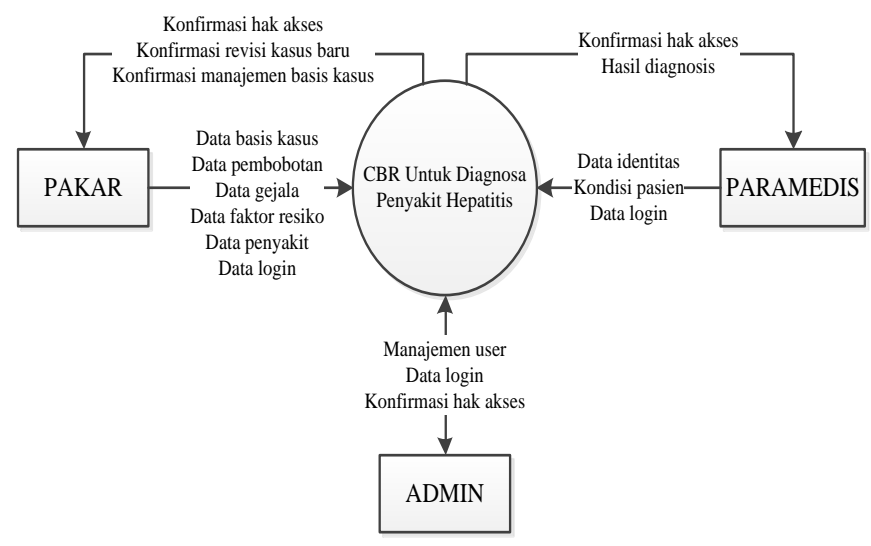

Gambar 1. Diagram Konteks Sistem CBR Untuk Diagnosis Penyakit Hepatitis

Pakar memasukan data-data kedalam sistem yang berupa data penyakit, data gejala, data faktor resiko, data pembobotan, dan data basis kasus kasus. Selain data-data tersebut, pakar juga melakukan revisi terhadap sebuah permasalahan baru. Sistem akan memberikan notifikasi ke pakar apabila terdapat kasus yang memerlukan revisi. Paramedis memasukkan identitas pasien dan kondisi pasien (gejala dan faktor resiko yang dialami pasien). Sistem akan mengeluarkan hasil diagnosa ke paramedis yang melakukan diagnosa. Paramedis juga dapat menyimpan permasalahan baru ke dalam sistem. Sedangkan admin merupakan entitas pengguna sistem yang berhubungan dengan tata kelola pengguna.

\section{Gambaran Sistem}

Arsitektur sistem yang digunakan pada sistem untuk dapat melakukan diagnosis penyakit hepatitis yang dibangun ditunjukan pada Gambar 2.

Pada tahap awal user (paramedis) menginputkan permasalahan berupa data pasien ke dalam sistem menggunakan modul input data yang dikembangkan berbasis GUI (graphical user interface). Data ini mencakup usia, jenis kelamin, gejala yang dirasakan, dan faktor resiko yang dialami pasien. Kemiripan permasalahan baru dengan kasus yang tersimpan dalam basis kasus dihitung pada proses retrieve menggunakan metode nearest neighbor. Kasus lama yang memiliki nilai similaritas tertinggi selanjutnya dipilih untuk menjadi kandidat solusi dari permasalahan yang diinputkan. Tahap ini disebut fase reuse dimana solusi kasus lama digunakan untuk menyelesaikan permasalahan baru. Kandidat solusi yang memiliki nilai similaritas < nilai threshold disimpan untuk dilakukan revisi oleh pakar. Sedangkan jika $\geq$ nilai threshold maka solusi dari kandidat solusi diambil 
sebagai solusi permasalahan. Hasil diagnosis inilah yang kemudian disampaikan kepada user sebagai pengguna melalui modul output.

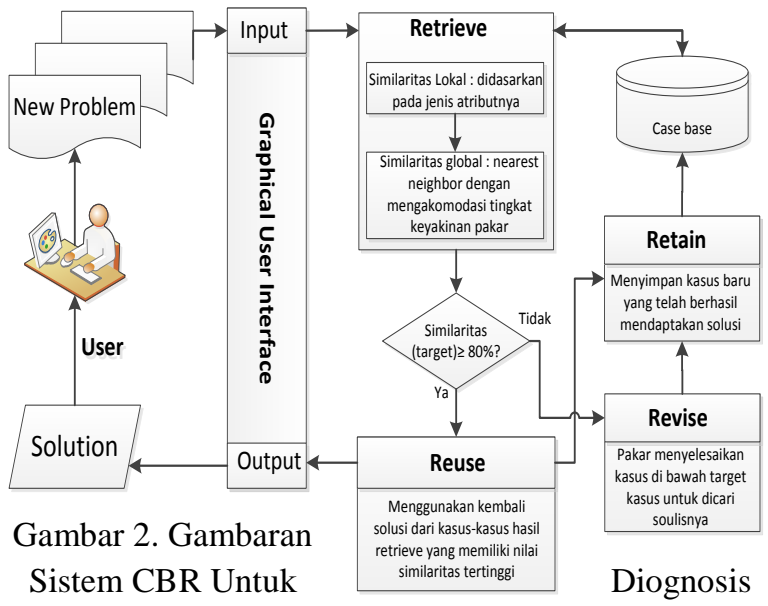

Penyakit Hepatitis

\section{HASIL DAN PEMBAHASAN}

\section{Proses Diagnosis}

Proses diagnosis pada sistem CBR ini dilakukan dengan cara memperhatikan gejala dan faktor resiko yang tampak atau dirasakan pasien (anamnesis) dan tidak menggunakan tes laboratorium. Komponen utama yang akan dihitung pada setiap basis kasus adalah usia, jenis kelamin, gejala dan faktor resiko. Usia pasien dihitung berdasarkan pembulatannya. Jenis kelamin terdiri dari laki-laki dan perempuan. Sedangkan gejala dan faktor resiko dinilai berdasarkan kemunculan suatu gejala atau faktor resiko dalam sebuah kasus. Jika gejala atau faktor resiko muncul maka gejala atau faktor resiko tersebut bernilai 1 (satu) dan jika tidak ditemukan bernilai 0 (nol).

Perhitungan similaritas antara permasalahan baru (target case) dan basis kasus (source case) dalam database basis kasus dilakukan pada setiap kasus yang memiliki kesamaan fitur. Jika nilai source case yang dibandingkan sama atau hampir sama dengan nilai target case maka solusi dari source case tersebut akan dipromosikan untuk menjadi solusi dari target case. Perhitungan kedekatan permasalahan baru dan suatu basis kasus dilakukan dengan perhitungan similaritas lokal dan similaritas global. Contoh kasus dalam basis kasus seperti terlihat pada Tabel 1. User melakukan diagnosa terhadap seorang pasien baru dengan data yang dimasukan kedalam sistem seperti terlihat pada Tabel 2.

Berdasarkan contoh kasus tersebut, maka sistem akan melakukan proses perhitungan similaritas antara permasalahan baru dengan kasus lama.

Tabel 1. Contoh Basis Kasus (Source Case)

Tabel 2. Contoh Permasalahan Baru (Target Case)

\begin{tabular}{|c|l|l|}
\hline No & \multicolumn{1}{|c|}{$\begin{array}{c}\text { No_RM } \\
(\mathbf{1 8 5 2 4 1})\end{array}$} & \multicolumn{1}{|c|}{ Keterangan } \\
\hline A & Kondisi umum & \\
\hline 1 & Usia & 37 \\
\hline 2 & Jenis Kelamin & Perempuan \\
\hline B & Gejala & \\
\hline
\end{tabular}

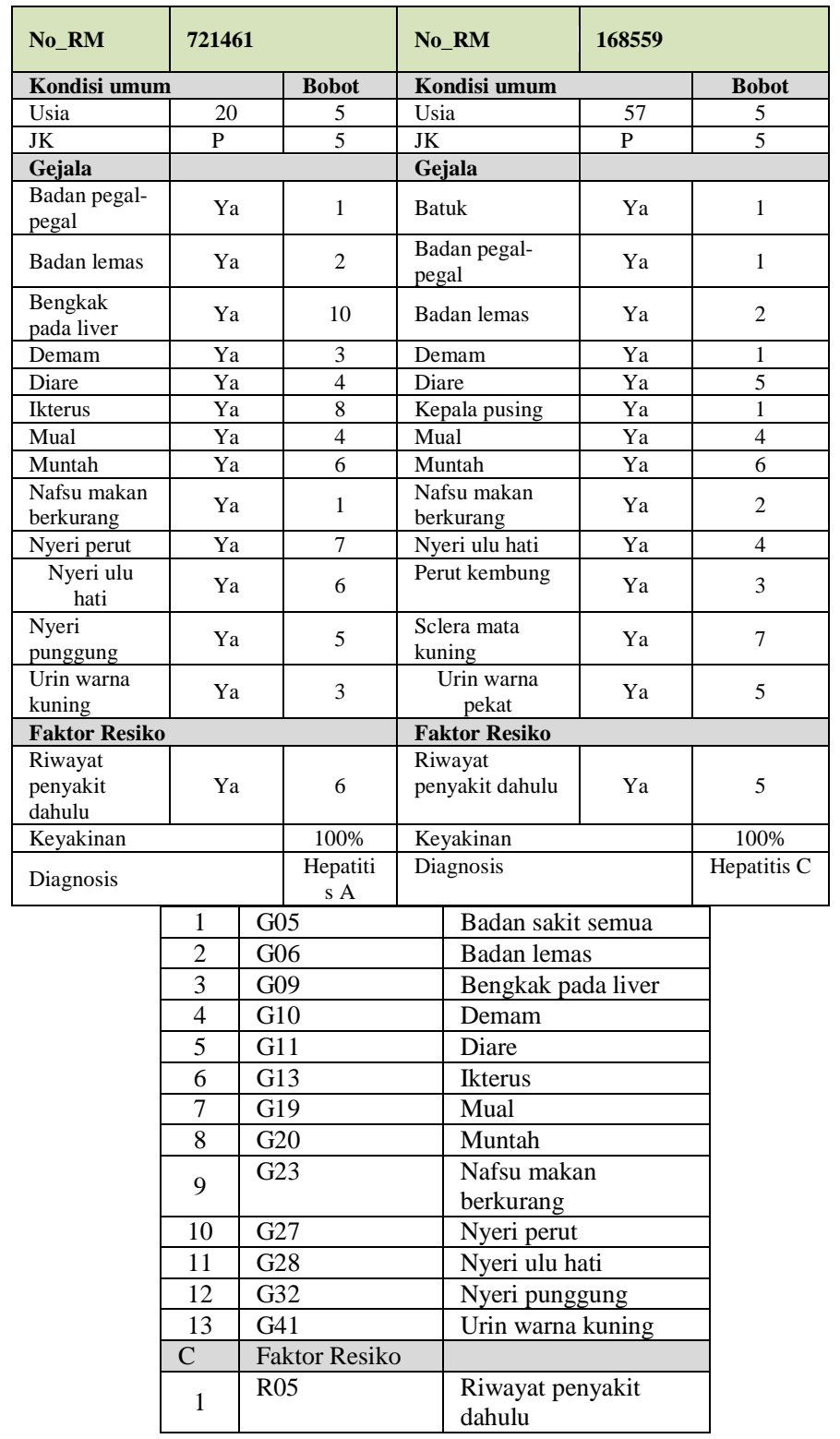

Berikut penjelasan masing-masing langkah perhitungan kedekatan kasus terhadap contoh pada basis kasus Tabel 1 dengan contoh permasalahan baru Tabel 2 :

\section{a. Similaritas Lokal}

1. Kemiripan target case (185241) dengan source case (721461)

a. Kedekatan fitur usia

$$
f(s, t)=1-\frac{|20-37|}{80-16}=0.73
$$

b. Kedekatan fitur jenis kelamin $=1$, karena jenis kelamin pada basis kasus dan permasalahan baru sama.

c. Kedekatan fitur gejala :

1. Gejala G06, G09, G10, G11, G13, G19, G20, G23, G27, G28, G32, G41 bernilai 1, karena kedua kasus memiliki gejala yang sama

2. Gejala G04 bernilai 0, karena hanya basis kasus yang memiliki gejala tersebut

3. Gejala G05 bernilai 0, karena hanya permasalahan baru yang memiliki gejala tersebut. 
d. Kedekatan fitur faktor resiko : R05 bernilai 1, karena kedua kasus memiliki faktor resiko yang sama.

2. Kemiripan target case (185241) dengan source case (168559)

a. Kedekatan fitur usia

$$
f(s, t)=1-\frac{|57-37|}{80-16}=0.69
$$

b. Kedekatan fitur jenis kelamin $=1$, karena jenis kelamin pada basis kasus dan permasalahan baru sama

c. Kedekatan fitur gejala :

1. Gejala G06, G10, G11, G19, G20, G23, G28 bernilai 1, karena kedua kasus memiliki gejala yang sama

2. Gejala G01, G04, G16, G34, G38, G42 bernilai 0 , karena hanya basis kasus yang memiliki gejala tersebut

3. Gejala G05, G09, G13, G23, G27, G32, bernilai 0 , karena hanya permasalahan baru yang memiliki gejala tersebut.

d. Kedekatan fitur faktor resiko : R05 bernilai 1, karena kedua kasus memiliki faktor resiko yang sama.

\section{b. Similaritas Global} dilakukan, selanjutnya dilakukan perhitungan similaritas global menggunakan persamaan (5) diperoleh :

Kemiripan target case (185241) dengan source case (721461)

$\operatorname{SimNN}(S, T)$

$(0.73 * 5)+(1 * 5)+(0 * 1)+(1 * 2)+(1 * 10)+(1 * 3)+(1 * 4)+(1 * 8)$ $\underline{(+(1 * 4)+(1 * 6)+(1 * 1)+(1 * 7)+(1 * 6)+(1 * 5)+(1 * 3)+(1 * 6))}$ $5+5+1+2+10+3+4+8+4+6+1+7+6+5+3+6$ $* 100$ $\% * \frac{15}{16}$

$$
\begin{aligned}
& =\frac{73.65}{76} * 100 \% * \frac{15}{16} \\
& =0.91 \text { atau } 91 \%
\end{aligned}
$$

Kemiripan target case (185241) dengan source case (168559)

\section{$\operatorname{Sim} N N(S, T)$}

$(0.69 * 5)+(1 * 5)+(1 * 2)+(1 * 1)+(1 * 5)+(1 * 4)+(1 * 6)+(1 * 2)$ $\frac{(+(1 * 4)+(0 * 1)+(0 * 1)+(0 * 1)+(0 * 3)+(0 * 7)+(0 * 5)+(1 * 5))}{5+5+2+1+5+4+6+2+4+1+1+1+3+7+5+5} * 100$ $\% * \frac{10}{16}$
Berdasarkan hasil perhitungan similaritas permasalahan baru terhadap basis kasus yang terdapat pada basis kasus (721461), diperoleh nilai similaritas menggunakan metode nearest neighbor sebesar 0,91 atau $91 \%$. Hasil perhitungan similaritas permasalahan baru terhadap basis kasus yang terdapat pada basis kasus (168559), diperoleh nilai similaritas menggunakan metode nearest neighbor sebesar 0,41 atau $41 \%$.

Dari hasil perhitungan similaritas permasalahan baru terhadap basis kasus yang terdapat pada basis kasus (721461) dan (168559), nilai kemiripan pada kasus (721461) lebih besar dari pada kasus (168559), sehingga dapat disimpulkan kasus yang paling mirip adalah kasus (721461). Kasus (721461) tersebut akan dipromosikan untuk menjadi solusi (hasil diagnosis) dari permasalahan baru tersebut. Seperti ditunjukkan pada Gambar 3.

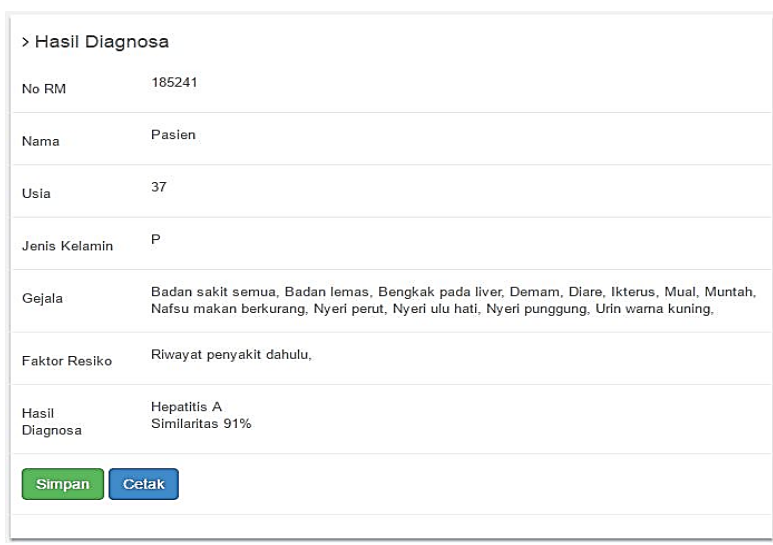

Gambar 3. Tampilan Hasil Diagnosis

\section{Pembahasan Hasil Pengujian}

Pengujian dilakukan dengan membandingkan hasil diagnosis sistem yang dibangun dengan diagnosis permasalahan baru yang telah divalidasi oleh pakar. Evaluasi hasil pengujian sistem dalam mendiagnosis penyakit hepatitis dilakukan dengan menghitung akurasi.

Prediksi akurasi secara keseluruhan dapat membantu untuk melihat rincian kinerja suatu pengklasifikasian, yaitu seberapa kelas $X$ yang benar diklasifikasikan sebagai kelas $X$ atau kesalahan klasifikasi sebagai beberapa kelas lain. Informasi ini disajikan dalam bentuk confusion matrix (Bramer, 2007). membuat confusion matrix berdasarkan masing-masing nilai similaritas hasil pengujian sistem, seperti terlihat pada Tabel 3. Rekapitulasi hasil pengujian dengan nilai threshold sebesar $80 \%$ diperlihatkan pada Tabel 3 dan diilustrasikan dalam bentuk grafik oleh Gambar 4 . Sumbu horisontal menunjukkan jenis penyakit dan sumbu vertikal menunjukkan jumlah diagnosis benar sesuai jenisnya.

Tabel 3. Confusion Matrix Hasil Pengujian

$$
\begin{aligned}
& =\frac{37.45}{57} * 100 \% * \frac{10}{16} \\
& =0.41 \text { atau } 41 \%
\end{aligned}
$$




\begin{tabular}{|l|c|c|c|c|}
\hline \multicolumn{2}{|c|}{} & $\begin{array}{c}\text { Hepatitis } \\
\text { A }\end{array}$ & Hepatitis B & Hepatitis C \\
\hline \multirow{2}{*}{$\begin{array}{l}\text { Actual } \\
\text { class }\end{array}$} & Hepatitis A & 18 & 2 & 0 \\
\cline { 2 - 5 } & Hepatitis B & 0 & 8 & 0 \\
\cline { 2 - 5 } & Hepatitis C & 0 & 0 & 7 \\
\hline
\end{tabular}

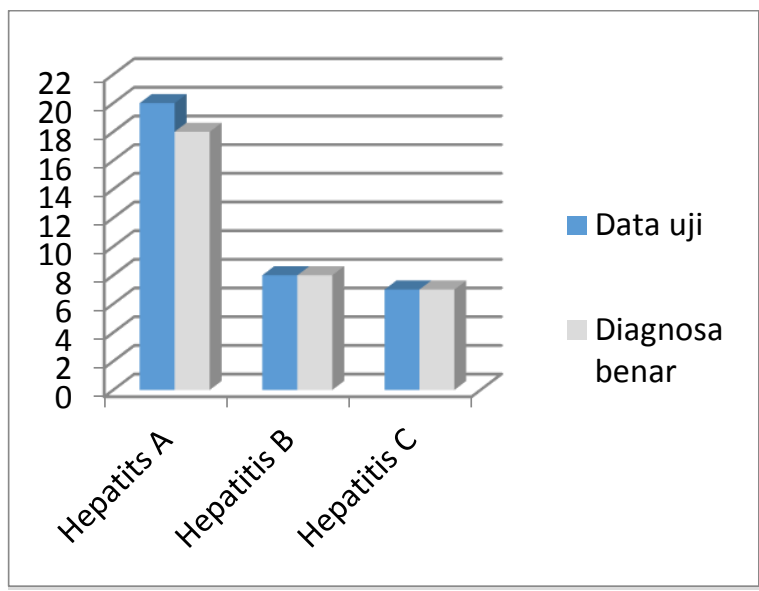

Gambar 4. Grafik Hasil Pengujian

Unjuk kerja sistem selanjutnya dapat dihitung dengan menggunakan persamaan

$$
\text { Akurasi }=\frac{33}{33+2} \times 100 \%=94,29 \%
$$

Hasil perhitungan di atas menunjukkan presentase kemampuan sistem dalam mengenali jenis penyakit hepatitis secara benar dengan tingkat akurasi sebesar 94,29\%.

\section{SIMPULAN}

Dari proses perancangan hingga pengujian yang telah dilakukan pada sistem CBR untuk diagnosis penyakit hepatitis, maka dapat diambil kesimpulan :

1. Penelitian ini menghasilkan sistem case-based reasoning untuk diagnosis penyakit hepatitis dengan memperhitungkan kemiripan antara permasalahan baru dengan kasus yang tersimpan dalam basis kasus menggunakan metode similaritas global nearest neighbor dengan mengakomodasi tingkat keyakinan pakar.

2. Hasil pengujian terhadap data uji penyakit hepatitis menunjukkan bahwa dengan nilai threshold similaritas global sebesar $80 \%$, sistem memiliki unjuk kerja dengan tingkat akurasi sebesar 94,29\%.l

\section{DAFTAR PUSTAKA}

[1] Althoff, K.D., 2001, Case-Based Reasoning,S.K Chang, Handbook of Software Engineering \&Knowledge EngineeringVol. 1,World Scientific, Singapore.

[2] Bramer, M., 2007, Principles of Data Mining, Springer-Verleg, London.

[3] Dienstag, J, L ., Isselbacher K, J.,2001, Toxic and Drug-Induced Hepatitis, di dalam: Braunwald E, Fauci AS, Kasper DL, Hauser SL, Longo DL, Jameson JL, Editor. Harrison's Principles of
Internal Medicine. Ed Ke-15 McGraw-Hill. New York.

[4] Jha, M.K., Pakhira, D., dan Chakraborty, B., 2013, Diabetes Detection and Care Applying CBR Techniques, IJSCE, 6, 2, 132-137.

[5] Mulyana, S., dan Hartati, S., 2009, Tinjauan Singkat Perkembangan Case-Based Reasoning, Seminar Nasional Informatika (SEMNASIF), ISSN 1979-2328, Yogyakarta, 23 Mei.

[6] Nurdiansyah, Y., dan Hartati, S., 2014, CaseBased Reasoning Untuk Pendukung Diagnosa Gangguan Pada Anak Autis, Tesis, Prodi S2/S3 Ilmu Komputer, Universitas Gadjah Mada, Yogyakarta.

[7] Ong, L., S., Shepherd, B., Tong, L. C., Choen, F. S., Ho, H. K., Tang. C. L., Ho. Y. S., dan Tan. K., 1997, The Colorectal Cancer Recurrence Support (CARES) System, Artificial intelligence in Medicine Elsevier, vol 11, 175-188.

[8] Pal, S. K., Shiu, S, C, K., 2004, Foundations of Soft Case-Based Reasoning. Wiley-Interscience Publication.

[9] Rismawan, T., dan Hartati, S., 2012, Case Based Reasoning Untuk Diagnosa Penyakit THT (Telinga Hidung dan Tenggorokan). IJCCS, 1, 1, 67-78.

[10] Tempola, F., Arief, A., dan Muhammad M, 2017, Combination Of Case-Based Reasoning And Nearest Neighbour For Recommendation Of Volcano Status. IEEE, Yogyakarta. Indonesia.,vol. 2, pp.348-352, [2017 2nd International Conferences on Information Technology, Information Systems and Electrical Engineering (ICITISEE)]

[11] Witten, I.H., dan Frank, E., 2005, Data Mining : Practical Machine Learning Tools and Techniques, 2, Morgan Kaufmann Publisher, San Fransisco 